\title{
Familien og felleskapets betydning i skoleelevenes selvpresentasjoner
}

\author{
Ane Malene Sæverot ${ }^{\star}$ og Ove Skarpenes \\ Institutt for pedagogikk, Universitetet $i$ Bergen, Bergen, Norge \\ Institutt for sosiologi og sosialt arbeid, Universitetet i Agder, Kristiansand, Norge
}

\section{Sammendrag}

I denne artikkelen undersøker vi hvordan norske videregående skoleelever presenterer seg selv. Elevene har tatt med et bilde de synes er viktig til intervjuet og dette dannet utgangspunktet for en refleksjon om hva de opplever er viktig i sitt liv og i samfunnet. Problemstillingen er todelt: Hva rapporterer skoleelever som viktig i sine liv og hvordan skal vi forstå det mønsteret som trer fram? Dataene antyder et kulturelt mønster hvor de unge søker etter kollektiv og grupper de kan knytte seg til heller enn å frigiøre seg fra.Vi spør derfor hvorvidt vi bør utvikle en tenkning om tilknytning snarere enn individualisering.

Nøkkelord: Ungdom; fellesskap; bilder; selvpresentasjoner

\begin{abstract}
In this study we explore how Norwegian pupils in upper secondary school present themselves. The pupils brought a picture of personal importance to the interview and this functioned as a basis for a reflection on what they feel is important in their lives and in society. The problem is twofold: What do schoolchildren report as important in their lives and how should we understand the pattern that emerges from these reports? The data suggests a cultural pattern in which the young are searching for something collective, including groups they can relate to rather than be freed from. On this background we ask whether we should develop a thinking about connection rather than individualization.
\end{abstract}

Keywords: Youths; community; images; presentations of the self

Received: October, 2016; Accepted: October, 2017; Published: December, 2017

^Korrespondanse: Ane Malene Sæverot, Postboks 7807, 5020 BERGEN. E-post: ane.saverot@, uib.no

(C) 2017 Ane Malene Sæverot og Ove Skarpenes. This is an Open Access article distributed under the terms of the Creative Commons Attribution 4.0 International License (http://creativecommons.org/licenses/by/4.0/), allowing third parties to copy and redistribute the material in any medium or format and to remix, transform, and build upon the material for any purpose, even commercially, provided the original work is properly cited and states its license. 


\section{Innledning ${ }^{1}$}

I denne artikkelen undersøker vi norske skoleelevers selvpresentasjoner gjennom fortellinger som elevenes egne medbrakte bilder genererer. Hvilke bilder velger ungdom å vise fram når de skal fortelle om det som er viktig i sine liv?

I de siste årene har ungdomskulturen fått stor oppmerksomhet i media og forskning. Det er ganske ulike historier om ungdom som blir presentert. En historie tar utgangspunkt i mangelfulle skoleresultater og svake rangeringer på de store internasjonale tester som sammenligninger skoleresultater (Sjøberg, 2014; Kjærnsli \& Olsen, 2013; Skarpenes \& Nilsen, 2014). Et element i denne historien er rapportene om 'frafall' og 'drop-outs' i skolesystemet (Lillejord m. fl., 2015; Vogt, 2017). Denne historien om ungdom skaper altså et bilde av en ungdomsgenerasjon som er lavt presterende, dropper ut av skolen og blir avvikere i samfunnet.

En annen historie vil vise fram en presset ungdomsgenerasjon som stresser, er overdrevent opptatt av sine prestasjoner som elev, venn, mediebruker, kroppskontrollør og som strever med å innfri alle samfunnskrav. Den kontroll og evalueringskulturen som har vokst fram de siste tiårene i skolen kan forstås som leddet som har omgjort selvrealisering fra en individuell mulighet til en selvtvang. Med andre ord har kanskje elevene internalisert den ytre kontrollkulturen og gjort den til en indre form for disiplin. Disse ungdommene portretteres i tv-programmer (Skam, Sykt perfekt, feg mot meg og Unge lovende) og bidrar med kronikker, debattinnlegg og filmer om seg selv. Ungdomsforskningen har identifisert en forsterket tendens til å prestere på skolen og i idrett, til å utsette og redusere alkohol-, tobakk- og narkotikabruk, utsette seksuell debut og til å være mer hjemme med familien. Denne ungdomskulturen har fått ulike navn: 'ungdom uten opprør' (Øia, 1998; Øia \& Fauske, 2010), 'generasjonskløfta som forsvant' (Øia \& Vestel, 2014) og 'generasjon lydig' (Aakvaag, 2013).

På den ene siden blir det skapt et bilde av en ungdomsgenerasjon som er lavt presterende og avvikere, mens nyere forskning har fått fram at dagens ungdom er en stresset og høyt presterende generasjon (Tylden, 2016, s. 1-6). Særlig dette siste bildet av ungdom har hatt gjennomslag. Også den siste rapporten fra NOVA med Ungdata 2016 (Bakken, 2016) støtter funn fra tidligere rapporter: ungdommen er flink, hjemmekjær, lite opprørsk. Nyere studier viser at familien har blitt viktig for ungdom, både i Norge (Øia \& Vestel, 2014; Bakken, 2016) og i andre land (Turtiainen, Karvonen \& Rahkonen, 2007; Irwin, 2009; Wyn, Lantz \& Harris, 2012). Samlet sett viser disse studiene at ungdom har et større fokus på familiefellesskapet enn tidligere.

\footnotetext{
${ }^{1}$ Denne artikkelen er en del av en doktorgradsavhandling knyttet til bilders pedagogiske betydning for ungdom og består av tre ulike perspektiv: 1. bilders eksistensielle betydning for ungdom (Sæverot, 2015), 2. bruk av bilder som metodisk virkemiddel for å få fram ungdoms selvpresentasjoner (denne artikkelen) og 3. den pedagogiske bruken av bilder i undervisning (Sæverot \& Ulvik, til vurdering).
} 
Rent tematisk er denne artikkelen forankret i den ungdomssosiologiske forskningstradisjonen, men vi har brukt en lite konvensjonell tilnærmingsmåte. Vi har bedt norske elever i videregående skole ta med et bilde de synes er viktig og latt det danne utgangspunktet for refleksjoner om hva de opplever er viktig i sitt liv og i samfunnet. Problemstillingen er todelt: Hva rapporterer skoleelever som viktig i sine liv og hvordan skal vi forstå det mønsteret som trer fram? For å belyse problemstillingen diskuterer vi i den teoretiske delen individualiseringstesen slik den er presentert i moderne sosiologiske samtidsdiagnoser. I denne diskusjonen deler vi individualiseringstesen i to «frigjøring fra» og «frigjøring til», for å ha begreper som mer presist rammer inn analytisk det empiriske caset vi drøfter. Vi finner at ungdommenes valg av bilder og deres begrunnelser for disse viser et ønske om forankring og fellesskap. Det sosiale fenomenet vi mener å kunne identifisere i våre data er ungdommens behov for forankring, og vårt forslag til terminologi er tilknytningstesen. ${ }^{2}$ Med bruk av det empiriske materialet og informert av nyere studier, utvikler og drøfter vi denne tilknytningstesen.

\section{Teoretisk innramming}

Vi har tatt utgangspunkt i sentrale resonnement som har blitt utviklet av sosiologene Ulrich Beck, Zygmunt Bauman og Anthony Giddens (BBG) i beskrivelsen av hvordan individualiseringstesen har tatt form. Tesen var at de gamle kollektivene som klasse, arbeids- og yrkesroller, familie og kjønn, det Beck kalte zoombiekategorier, ville om ikke forsvinne, så minske i betydning. Beck skriver at «class distinction based on status has lost their traditional support, and processes for the 'diversification' and individualization of lifestyles and way of life have been set in motion» (Beck, 1992, s. 91-92). Når individet i større grad blir frikoblet institusjonene, innebærer det både en frihet og en ny type usikkerhet. Det blir individets oppgave å forme sitt eget liv og finne biografiske løsninger (også når det det er systemskapte forskjeller) (Beck, 1992; Beck \& Beck-Gernsheim, 2002). Bauman formulerer det slik at i en individualisert utgave av moderniteten vil byrden ved å veve mønstre og ta ansvar for det som mislykkes falle på individets skuldre (Bauman, 2001, s. 18). Det er «karakteristisk for moderniteten at selvrealisering blir helt avgjørende for selvidentiteten» (Giddens, 1997, s. 113). Giddens snakker om en "frihet til» å velge sitt eget liv og han bruker begrepet om livspolitikk. En sterk individualiseringstese vil hevde at klasse, kjønn, familie- og geografisk bakgrunn og yrkesvalg ikke lenger er relevant, mens en svakere tese vil hevde at disse klassiske sosiologiske variablene har fått mindre påvirkningskraft enn tidligere (Krange \& Øia, 2005, s. 160). Denne formen for individualisering som BBG fremhever peker på at individet i større eller mindre grad er frigjort fra sosiale bånd og roller som vi konvensjonelt knytter til disse variablene. Samtidig blir subjektene frigjort til et samfunn hvor de institusjonelle rammene er mindre tydelige og ansvaret for valg i stadig større omfang overlates den enkeltes.

\footnotetext{
${ }^{2}$ Så vidt vi vet er det ingen som har brukt begrepet tilknytningstese i denne sammenheng tidligere.
} 
Individualiseringstesenes «frigjøring fra» - dimensjon er mye kritisert. Vi kan ta for oss én av de tradisjonelle variablene, nemlig klasse/sosial bakgrunn, og peke på at BBGs tese om at klassebakgrunn ville få langt mindre betydning, ble om ikke gjendrevet, så eksplisitt problematisert empirisk i Norge av Lars Ove Seljestad (2003) og Julia Brannen \& Ann Nilsen (2005). Videre viser fremdeles ulik klassebakgrunn ulike livssjanser (Hansen \& Engelstad, 2010) og i den anglosaksiske litteraturen er klassebegrepet til Beck og Giddens blitt eksplisitt kritisert (Atkinson, 2010) og implisitt problematisert (f.eks. Lareau, 2002).

Når det gjelder den andre delen av individualiseringstesen, som vi i denne sammenhengen har kalt for «frigjort til» - dimensjonen, er behandlingen i faglitteraturen en noe annen. BBG vil være opptatt av at individene er tvunget til selvfleksjon og de må også selv ta ansvar for ikke realiserte mål og mislykkede prestasjoner. Også sosiologer som f.eks. Richard Sennett (1998), Pierre Bourdieu (1999) og David Harvey (2005) vil argumentere for at samfunnsproblemer blir individualisert i det de vil kalle for det nyliberale samfunnet. Så enten man kaller samfunnet nyliberalt eller senmoderne er sosiologene enige om at det preges av en type individualisering hvor de institusjonelle (ofte trygge) rammene som individene skal realisere seg innenfor blir utydelige (arbeidslivet, utdanningssystemet, velferdsstaten) og mindre gunstige. I den allerede klassiske studien av moderne arbeidsliv, viste Sennett (1998) hvordan individuell identitet kunne smuldre opp i et arbeidsliv hvor arbeidstakerne var tvunget til individualisering ved å være fleksible, endringsvillige og mobile i et arbeidsliv der alt alltid var i endring.

Når de institusjonelle rammene som selvrealiseringen skal foregå innenfor blir utydelige, kan denne siden av individualiseringstesen - frigjøring til - delvis bli problematisk. Individet trenger tydelige rammer ellers blir individualiseringen grenseløs (anomisk). Seksualiteten og kroppen kan alltid bli bedre og det er enkeltindividets frihet til å fikse det (Giddens, 1994; Helseth, 2012), og er det problemer på jobb eller andre steder som fagforeninger eller velferdsstatlige ordninger kunne håndtert, oppfordrer vår kultur oss til kurs i mindfulness, selvledelse - det er innover vi må gå (Madsen, 2014). Det som er en "frihet til» blir stadig oftere et «ansvar for» egen (gode) læring, ansvar for egen (harmoniske) selvutvikling, ansvar for egen (perfekte) kropp, ansvar for egne (mange) likes på sosiale medier, ansvar for eget (aldri kjedelige) sex- og kjærlighetsliv (Giddens, 1994) og arbeidslivet prekariseres (Standing, 2014). Dette senmoderne samfunnet krever at individet er selvrefleksivt.

Ungdommen som vi studerer er frigitt til denne prestasjonskulturen. Denne kulturen er et samfunnsfenomen vi trenger mer innsikt i. Ved bruk av de diskuterte begrepene frigjort til og frigjort fra skal vi drøfte hvordan ungdommene forholder seg til denne kulturen.

\section{Metodologi}

For å belyse denne problematikken har vi benyttet oss av bilder i undersøkelsen av hva skoleelever opplyser som viktig i sine liv. Bruk av foto har blitt stadig vanligere $i$ empirisk samfunnsforskning. F.eks. argumenterer Gillian Rose (2012) for at bilder 
gir informasjon om et fenomen på en annen måte enn konvensjonelle data og at det derfor kan være hensiktsmessig å la informantene medbringe bilder til intervjusituasjonen (photo-elicitation). I boken Using visual data in qualitative research viser Marcus Banks (2007) blant annet hvordan bruken av visuelle tilnærminger kan være en god måte å «se» verden fra informantenes perspektiv. På denne måten bidrar bilder til å fremskaffe et rikere material (se også Vassenden \& Andersson, 2010; Nilsen, 2016). I et forsøk på å komme tettere inn på ungdommens egne forestillinger om hva de opplever som viktig i sine liv og hvorfor, har vi i denne artikkelen derfor bedt informantene ta med bilder som er viktige for dem. Informantene reflekterer rundt bildene $\mathrm{i}$ intervjusituasjonen. Bildene er dermed et middel til å få skoleelevenes selvrefleksjon i gang og generer personlige fortellinger. Måten bildene ble brukt på var i utgangspunktet en metode vi mente kunne gi ny kunnskap om skoleelevene.

I tillegg til denne mer instrumentelle måten å forholde seg til bildene på, knyttes bruken av bildene også til en epistemologi. Denne er hentet fra arbeidene til Jacques Rancière. Vi har tidligere brukt Rancière (2009a, 2009b, 2011) for å utvikle et argument om viktigheten av et ideal om epistemologisk symmetri. Med det tenker Rancière på at forskeren skal la informantene styre de dataene som skapes og som senere tolkes. Dette kan gi bedre mulighet for en diskusjon på informantenes egne premisser, og at det kan legge til rette for det Rancière kaller en demokratisering av det sosiale. Rancière har utviklet dette resonnementet $i$ tilknytning til en studie av symmetriske relasjoner mellom elever og lærere. ${ }^{3}$ Det er denne ambisjonen som er overført til det metodologiske designet. I undersøkelsen var vi interessert i å legge så få føringer som mulig på hva informantene kunne si. Slik tilstrebet vi å skape situasjoner der den enkelte ble gitt muligheten til å bringe inn sine egne personlige erfaringer, fremfor å bli møtt med forhåndsdefinerte spørsmål. Når den enkelte får muligheten til å dele sine erfaringer, og gis mulighet til å uttrykke seg på fritt grunnlag, da kan den enkelte realisere seg i den aktuelle situasjonen (Biesta, 2014, s. 143). Dette var idealet som ble forsøkt etterfulgt under intervjuene. Det vil si at intervjueren forsøkte å skape et rom for at den enkeltes historie kunne komme til uttrykk. Det innebærer at hver informant skulle gis mulighet til å få dele sine erfaringer, og ikke minst at disse erfaringene ble gitt en verdi som var jevnbyrdig med andres erfaringer. Målet var at deres refleksjoner og tanker kunne tre frem på mest mulig usensurert vis. Samtidig er det viktig å unngå mistolkninger. Hvordan skal en tolke dataene og samtidig forsøke å opprettholde ambisjonen om epistemologisk symmetri? Dette spørsmålet ble stilt for å unngå faren for å mistolke informantene (jf. Bingham \& Biesta, 2010). Symmetri er en ambisjon og det er også grunnen til at vi har valgt å bruke mange sitater, for på den måten å sikre, i størst mulig grad, lydhørhet overfor dataene. I stedet for å giøre forsøk på å avsløre eller forklare hva informantene egentlig

\footnotetext{
${ }^{3}$ En slik symmetri kan ikke gjelde i alle undervisningssituasjoner, det vil ikke Rancière heller mene, men det kan fungere som utgangspunkt i noen viktige pedagogiske situasjoner hvor elevene skal gis en mulighet til å vise hva de står for politisk, religiøst, moralsk, estetisk osv. I en annen artikkel omtaler vi dette som epistemologisk symmetrisk ideal (Skarpenes \& Sæverot, 2018).
} 
sier, har vi forsøkt å løfte frem deres historie, slik at denne særegne og unike historien kan tre frem i verden. Dataene som skal tolkes i denne undersøkelsen er fortellinger knyttet til bilder. Oppgaven har i så måte bestått i å tolke ulike personlige fortellinger og ofte barndomsminner som igjen kan fortelle oss noe om hvordan den enkelte gir uttrykk for sine tanker og refleksjoner. Alle har sine personlige opplevelser og fortellinger som er unike, men fortellingene er likevel mer enn individuelle idiosynkrasier. I beskrivelsene av sine erfaringer forbinder nemlig ungdommene sine personlige opplevelser med kulturelt forankrede kollektive kategorier. Men andre ord forbinder de enkelte individene sine subjektive erfaringer med ulike kollektive erfaringer (eller generelle kategorier).

Det er foretatt et strategisk utvalg av informanter for å få frem stemmene til et relativt bredt spekter av ungdom i videregående skole. Vi henvendte oss til skoleledelsen ved fem ulike videregående skoler og presenterte prosjektet. Deretter ble vi satt $\mathrm{i}$ kontakt med aktuelle lærere som opprettet kontakt med elevene på bakgrunn av utvalgskriteriene våre. Slik fikk vi kontakt med elever fra ulike klasser med forskjellige fagkombinasjoner. Alle informantene er over 18 år og det er en relativt jevn fordeling mellom jenter og gutter. To av informantene har en annen etnisk bakgrunn enn norsk. Det ble i alt gjennomført 13 intervjuer. Intervjuene ble gjennomført på grupperom på de ulike skolene og varte alt fra 20 til 50 minutter. Førsteforfatter av denne artikkelen gjennomførte intervjuene, som ble tatt opp med en diktafon og etterfølgende transkribert. Informantene er anonymisert og det brukes fiktive navn. Prosjektet er godkjent av Norsk senter for forskningsdata (NSD). Siden intervjuene var frivillige kan vi anta at det var elever som var positivt innstilt som deltok. Ved å rekruttere ungdom gjennom skoleinstitusjonen får vi ikke kontakt med de elevene som dropper ut av skolen. Det empiriske materialet kan på bakgrunn av dette bære preg av at det hovedsakelig var velfungerende ungdom som ble rekruttert og at det empiriske materialet derfor har mangler.

I forkant av intervjuene ba vi informantene om å ta med et bilde som på en to eller annen måte var betydningsfullt for dem. Dette bildet ble utgangspunktet for intervjuet med hver enkelt informant. De sto fritt til å ta med et hvilket som helst bilde, eksempelvis maleri, fotografi, kunstbilde, familiebilde og liknende. Slik forsøkte vi å finne ut hvilke bilder som kunne anses som betydningsfulle i den enkelte ungdommens liv. Informantene ble bedt om å beskrive det utvalgte bildet og videre fortelle om hvilken betydning det har i deres liv. Vi spurte eksempelvis om: Hvorfor har du medbrakt akkurat dette bildet? Hvilke deler av livet ditt relaterer dette bildet til? Samtalen satte i gang et refleksjonsarbeid og dette kom til uttrykk ved at informantene blant annet endret sine refleksjoner og synspunkter underveis.

\section{Hva fortalte skoleelevene om bildene de hadde med?}

Hva slags bilder har de med og hva rapporterer de som viktig i sine liv? Informantene hadde med seg svært forskjellige bilder. Familiebilder, barndomsbilder, portretter, kunstbilder, naturbilder, politiske og religiøse bilder. Hovedsakelig presenterte 
informantene positive fortellinger knyttet til bildene. Det var alt fra gode minner til nære og positive relasjoner. Samtidig kunne vi også ane underliggende sårhet i fortellingene, det kunne være savn av foreldre, besteforeldre eller kjæledyr, skuffelse og vemod på grunn av idrettsskader, lengsel etter tapt barndom. Informantene fortalte historier fra sin barndom, viktige hendelser i livet og episoder fra hverdagsliv. Vi fant også at de medbrakte bildene virket forløsende, på den måten at bildene satte i gang fortellinger og refleksjoner som i stor grad dreide seg om opplevelser vedrørende den enkeltes forhold til omgivelsene sine.

To aspekter som særlig pekte seg ut var betydningen av familie og andre former for felleskap og trygghet. I den teoretiske delen splittet vi opp modernitetsteoretikerne sin individualiseringstese $\mathrm{i}$ en «frigjøring fra del» og en «frigjøring til del». Vi skal la dette analytiske skillet ramme inn diskusjonen videre. Hvis vi tar utgangspunkt i det samfunnet elevene er "frigitt til», kunne vi kanskje ha forventet at de hadde valgt andre bilder som kunne signalisere betydningsfulle temaer i tiden. Det kunne for eksempel dreie seg om større tema som kjennetegner det risikosamfunnet de er en del av og frigjøres til, globale tema som miljø, krig, sult, økologi. Det er lite protest mot slike samfunnsskapte risikoer i empirien. En tolkning kan være at spenningene mellom generasjonene har forsvunnet og siden foreldregenerasjonen ikke refleksivt bringer opp farene i risikosamfunnet, gjør heller ikke barna det. For 40 - 50 år siden kom generasjonskonfliktene til uttrykk i musikk, mote og andre kulturformer, og det ble også tydelig i politiske demonstrasjoner mot kriger, kapitalisme og etter vært også miljøødeleggelser. Endringene var akkompagnert av et friere forhold til alkohol, narkotika og sex. Slike generasjonsforskjeller er langt mindre i dag (Øia \& Vestel, 2014). Og dagens opprør har mindre potensial for å provosere, fordi kulturuttrykkene så raskt suges inn i den kommersielle mainstreamkulturen. Det er bare Frida som har med et bilde som snakker om et politisk tema. Hun har med seg en feministisk propagandaplakat og ønsker å fremme og diskutere kvinners frigjøring som kollektiv. Men dette er et unntak.

Når skoleelevene blir bedt om å ta med et bilde som betyr noe for dem, er det ikke så underlig at dette fenomenet «drop-out» ikke er sentralt i deres fortellinger. Men det er likevel kanskje litt rart at det ikke dukker opp i samtalene i det hele tatt som noe de kunne ha lyst til å diskutere eller forsvare seg mot. Dette er en generasjon som har blitt drillet i utviklingen av de fem ferdighetene. Samtidig er dette en skole som har nedprioritert historie, geografi, samfunnsfag, fremmedspråk, kunst, filosofi, etikk, musikk, litteratur og praktiske eller estetiske fag (Sjøberg, 2014). Dette skaper et mindre mangfold i skolen og etablerer nye former for normalitet og avvik (Skarpenes \& Nilsen, 2014).

Videre kunne en ha forventet at de hadde ønsket å tematisere denne frigjøring til dimensjonen på et individuelt nivå ved vise bilder som på ulike måter viste fram generasjonens selvrefleksivitet knyttet til skoleprestasjoner, trening, mote, klær, musikk, sminke, kropp, venner, kontakter på sosiale medier osv.. Men dette er heller ikke sentralt i intervjuene. Det er verken senmodernitetens samfunnsmessige risikoer eller senmodernitetens selvrefleksive og individuelle prestasjonskultur som i særlig grad 
trekkes fram gjennom elevenes bilder og fortellinger. I den grad denne kulturen trekkes fram overhodet er det som noe generasjonen tar avstand fra og er mindre opptatt av at dette er noe de blir frigjort til. Fravær av slike bilder og tematikker (kropp, venner, sosiale medier, karriere, vellykkethet) er slående, og denne delen av frigjøring-tildelen av individualiseringstesen er nesten fraværende i dataene.

Samtidig er det kanskje ikke underlig at mange tar med bilder som genererer fortellinger om nære relasjoner når de blir bedt om å ta med bilder som er betydningsfulle. Men det er viktig å forstå at disse bildene og de fortellingene som genereres er vitnesbyrd om en tilknytning til familien snarere enn frigjøring fra familien som et påtvungent identitetsfelleskap. Elevene vender seg mot familien og fellesskapene for å søke tilknytning. Kanskje er det naturlig å snakke om fellesskapsrefleksivitet i tillegg til den individualiserte selvrefleksivitet som fremheves i den konvensjonelle senmodernitetsteorien. Fortellingenes temaer har vært det styrende prinsipp når vi har utformet de ulike kategoriene. Et funn er svært fremtredende i materiale: Orienteringen mot de nære relasjoner. Nær sagt alle intervjuene graviterer mot en diskusjon av de nære familiære relasjonene og andre typer av felleskap som betyr veldig mye for langt de fleste av ungdommene som vi har intervjuet og samtalt med. Det kan se ut til at informantene ønsker å være noen uten å måtte være noen i kraft av hva de presterer. På bakgrunn av dataene presenterer vi tre tema; familien, felleskapet og flukten.

\section{Familie}

Som vi så ovenfor mente Beck at industrisamfunnets institusjoner (blant annet kjernefamilien) vil forvitre og samfunnets fundament revne. Bauman er enig og siterer Beck:

Spør deg selv: Hva er egentlig en familie nå for tiden? Selvsagt finnes det barn, mine barn, dine barn. Men selv det å være foreldre, kjernen i familielivet, har begynt å gå i oppløsning... (Beck sitert i Bauman, 2001, s. 17).

Bauman synes å argumentere for at den viktige institusjonelle rammen som familien utgjorde er i ferd med å «smelte ned» i vår tid. Barna tvinges til å frigjøre seg fra denne institusjonen som enten er i oppløsing eller i hvert fall ikke lenger kan tilby identitet og trygghet. De ungdommene som er intervjuet i denne studien synes å ha et noe annet forhold til familien, og de dataene vi har utfordrer denne frigjøring fra delen av individualiseringstesen.

Peter snakker om familien sin gjennom hele intervjuet. Underveis i intervjuet begynner han å reflektere rundt et bilde av hans bror og han selv.

Det eneste bildet som jeg elsker, som jeg liker mest, er et hvor jeg er rundt 1 år, veldig liten, og så står min bror ved siden av meg, han var rundt 5 år. $O g$ så mye som min mor og bestemor har fortalt meg, at han beskyttet meg hele tiden, han var veldig forsiktig med meg og sånt. Så det er veldig mange følelser med det bildet. [...] 
Jeg elsker min bror. Han er familie. Du burde elske familien din. Ingen kan støtte deg som familien. Det er i alle fall det jeg tror (Peter).

Det er tydelig at familien betyr mye i denne unge guttens liv. Han snakker om familien som det viktigste holdepunkt i livet, hvor støtte, beskyttelse og omsorg gis. Peter hadde også tatt med et portrettbilde av ham selv i kamppositur. Han har drevet med denne individuelle idretten på et profesjonelt nivå og har brukt mye tid på trening og av den grunn har han måttet forsake mange typiske ungdomsaktiviteter. Han fortalte også at han hadde blitt skadet og at han derfor måtte avstå fra trening i lengre perioder. Skaden betydde slutten på idrettskarrieren. Selv tenker og reflekterer han slik om portrettbildet:
Det bildet er tatt for to år siden. Rett før verdensmesterskap. Så jeg var i veldig god form. Og min mor ville ta det for historien sin skyld. Vi tar ikke så mange bilder, $\mathrm{i}$ hvert fall ikke av meg og min bror, vi pleier ikke å ta bilder i det hele tatt. Også min mor reiste tilbake til xxx for å støtte meg. Og så spurte hun om jeg kunne ta bilde for henne, siden det er så stor betydning for meg, denne offisielle kampen. [...] Så hun ville at vi skal huske det. Og at hun skal vise det til mine barn og så videre. Så de skal se på meg når jeg var 17 år (Peter).

Peter forteller at han fikk deltatt på verdensmesterskapet, men ble deretter skadet og måtte slutte. Samtidig måtte han også flytte til Norge med familien. Begge disse hendelsene innebærer store forandringer for ham. Selv forteller han at det var en tung omstilling. Han måtte lære seg et nytt språk, finne nye venner og bruke tiden på skolearbeid. Han sier selv at han er en helt annen person nå enn da han ble avbildet på det medbrakte bildet. Der portrettbildet sender ut signaler om kraft, styrke, modighet og lignende, sender han i samtalen og selv-refleksjonene ut signaler om viktigheten av familiefellesskap.

Det som kommer frem i fortellingene er at han tidligere var mer fokusert på å være en sterk og modig idrettsutøver. Kanskje har han fortsatt dette bildet av seg selv, men det lyser også gjennom noe annet. Han synes nemlig å ha et større bevissthetsforhold til viktigheten av familiefellesskap. Fortellingene avdekker at han alltid har vært familiekjær, men graden av bevissthetsforhold synes å ha blitt sterkere etter skaden og utvandringen til Norge.

Globaliseringen og internasjonaliseringen av arbeidslivet og dets tilbud om $/ \mathrm{krav}$ til mobilitet/flyt av arbeidskraft fører til flytting. Peter og hans familie er et eksempel på denne samfunnsendringen. Her kunne en kanskje ha snakket om at disse omstillingene ville føre til en tvunget frigjøring fra storfamilien og en oppløsning av kjernefamilien som ramme for identitet og trygghet. Innenfor en slik tolkning ville familien fremstå som det Bauman kaller et savnet felleskap. For Bauman gir fellesskap løfter om gleder, noe vi i den vestlige verden synes å mangle (2000, s. 33). Men hos Bauman representerer familien er fravær som representerer er tap i det senmoderne samfunnet, og derfor framstår frigjøringen fra familien som et savnet felleskap. Men Peter verken er, eller ønsker å være frigjort fra familien, tvert imot er han i familien og bruker den som trygghet og ramme i livet. En tolkning kunne vært at familien blir ekstra 
sentral for innvandrere før de er integrert i andre samfunnsinstitusjoner. Imidlertid viser dataene at også de som er født og oppvokst i Norge gir lignende signaler om drømmer og håp etter et familiefellesskap. Et eksempel er Albert som valgte å snakke om Rembrandts kjente maleri Nattevakten som henger i Reijkmuseum i Amsterdam, et bilde han er svært glad i. Albert forteller om sitt møte med det verdenskjente maleriet:

Det betyr veldig mye for meg fordi at moren min og søsteren min har snakket veldig mye om det i ganske lang tid. De er veldig begeistret over det. Og for en stund siden da, jeg tror det var i fjor, at vi reiste til Amsterdam da, til det museet, og at jeg endelig fikk se det med mine egne øyne. Og det er en veldig storslagen opplevelse da, siden det er kjempestort. [...] Og jeg bare syns det var en helt fantastisk opplevelse å se det med egne øyne. Og så er jeg jo veldig interessert i kunst fra før da. Det er vel det jeg prøver å utdanne meg i, noe kreativt, som har med maling eller... i hvert fall digital kunst da. Så det var litt av det, litt av grunnen til at jeg er så glad i det bildet (Albert).

Vi ser at Albert er begeistret over selve bildet, Nattevakten. Årsaken har å gjøre med moren og søsteren hans. Det er de som har fått han interessert i Nattevakten. De har snakket mye om nettopp dette bildet med ham. Det er familien som har hatt stor betydning for hans valg av interesser og utdanningsretning. Ifølge hans egne fortellinger har ikke familien på noen som helst måte presset på i en viss utdanningsretning. Familien og deres valg har snarere vært til inspirasjon for hans egne valg om utdanning og yrke. Familiens betydning kommer kanskje enda klarere til uttrykk gjennom Karstens refleksjoner:

Ja, det bildet det er da familiebildet vi tok i sammenheng med min farfar sin 60-årsdag, der vi da samlet hele familien [...] Med minner om familie. Jeg tenker at familie må du ha kontakt med og sånn der. Familie er viktig. Det ikke så veldig mange som tar seg tid til å besøke for eksempel besteforeldre og sånt. Jeg tenker at familien er såpass viktig at det er ofte jeg er oppom på besøk til dem. [...] Jeg kommer for eksempel opp til de etter skoletid eller noe sånt. Så spiser vi noe lunsj og sitter og snakker. [...] Så var det ikke så lenge siden, da hjalp han meg med et skoleprosjekt, som gikk ut på min oldefar, som levde under andre verdenskrig (Karsten).

Heller ikke for Albert og Karsten representerer familien noe fraværende. Det er et tilstedeværende felleskap. Også for de norskfødte er familien svært viktig, så når Bauman påpeker at «borte er de fleste stabile og godt rotfaste orienteringspunktene som bar bud om et sosialt miljø mer varig, mer trygt og mer pålitelig enn den enkeltes egen levetid» (2000, s. 84) og han regner inn familien blant disse forsvunne orienteringspunktene "forholdene virker dessuten ikke særlig stødigere innenfor hjemmets fire vegger enn ute i gatene» (ibid, s. 83), er det en påstand som ikke finner særlig støtte i vårt datamateriale. I fortellingene vi har redegjort er familien nettopp et rotfast orienteringspunkt.

Ungdom, slik den framstår i empirien vår, preges ikke bare lite av individualiseringstesen $\mathrm{i}$ betydningen frigjøring fra familien, men den preges mye av dennes 
antitese. Nærmere bestemt er det avgjørende for flere informanter å knytte seg til familien som et kollektivt prosjekt. At familien igjen er viktig kjenner vi også igjen fra store ungdomsstudier i Norge (Øia \& Vestel, 2014; Bakken, 2016). Videre finnes det også internasjonal litteratur som direkte har diskutert familiens betydning i ungdommens liv. I en studie av finske ungdommer kom det fram at ungdommene brukte mer tid hjemme og at fellesmåltider hadde blitt viktigere. Gode familierelasjoner var viktig for ungdommene og de satte pris på å ha et varmt og åpent forhold til foreldrene. Familien og foreldrene tilbyr sikkerhet og mulighet for tilbaketrekning også ved bare å være tilgjengelig dersom det var ønskelig (Turtiainen m. fl., 2007, s. 489-491). Et godt familieliv var avgjørende for at ungdommene skulle ha det bra. Sarah Irwin argumenterer også for at familiens betydning er «extremely important» for britiske ungdommer (Irwin, 2009, s. 351). Ved å ta utgangspunkt i hvordan ungdommene erfarer familielivet viser hun hvor viktig familiens «emotional support» er for å lykkes i livet. Familiens støtte er avgjørende for akademisk motivasjon, og klassebakgrunn styrer hvilke forventninger de har til utdanning (Irwin, 2009). Både finske og britiske ungdommer viser hvor viktig familien er for å ha det godt med seg selv og for lykkes med andre ikke-familiære aktiviteter (skole, jobb osv.). Dette er ungdommen selv klar over. Kanskje enda tydeligere er Wyn m. fl. (2012) i deres arbeid om australske ungdommer. De viser at ungdommene er sterkt forankret i familiefellesskapet. Ungdommene er opptatt av familiemedlemmenes helse og velvære (happiness), og forskerne viser hvordan familiemedlemmene er gjensidig avhengig av hverandre gjennom følelsesmessige, fysiske, psykiske og åndelige relasjonelle fellesskap (Wyn m. fl., 2012, s. 15). Familien er også avgjørende for å forme ungdommen sosiale og politiske bevissthet. Det kommer fram av studien at ungdommen ikke bare inngår i et gjensidig avhengighetsforhold med resten av sin familie, men at den også er klar over hvor viktig dette er. De empiriske dataene våre støtter opp under dette funnet.

Også informantene vi har presentert viser innsikt i betydningen familien har for deres velvære og deres valg (også innen utdanning). Deres refleksivitet vender seg mot familien som kollektiv. Wyn m. fl. går imidlertid lengre i sine tolkninger. Ikke bare er det slik at familien som institusjon er viktig i det senmoderne samfunnet, men selve ideen om løsrivelse - at ungdom er i en overgangsfase - hvor de skal frigjøre seg fra familien til et uavhengig og selvstendig liv, blir av Wyn og hennes kolleger problematisert. Det er slik at "transitions are cleary very important», og mange av de australske ungdommene er opptatt av dette og betydning av utdanning. Men disse «transistions are supported and mediated through the experiences of family life and young people's own accounts recognize inter-dependence, mutual support and sharing common goals" (Wyn m. fl., 2012, s. 19). De utenlandske studiene understreker den store betydningen av gjensidig avhengighet innen familien. Det er vanskelig ikke å se de fortellingene vi kort har gjort rede for om familiær emosjonell støtte, utdanningsinspirasjon og besteforeldres hjelp til skoleprosjekt, som norske eksempler på dette fenomenet. Informantenes utsagn kan ikke tolkes som et savn etter familieinstitusjonen som har gått i oppløsning i senmoderniteten, eller som en institusjon man 
refleksivt er tvunget til å frigjøre seg fra. Fortellingene bør tolkes som en refleksiv tilknytning til familien som institusjon, og at ungdommen har innsikt i familiens betydning for dem på mange områder i livet.

\section{Felleskap og flukt}

Også andre fellesskap enn familien har betydning. Allerede på 1980-tallet snakket forskere om en ungdomsmasse uten opprør (Grue, 1987). En kan skille mellom proog protestkulturer. Prokulturer vektlegger politisk korrekte og samfunnsmessige normer og verdier. Det kan for eksempel være fokus på gode idrettsprestasjoner eller gode skoleprestasjoner. Protestkulturer, derimot, utfordrer samfunnets normer og verdier og vil typisk være kulturer som aksepterer og fremmer rus og vold (Heggen \& Øia, 2005, s. 116). I følge norsk ungdomsforskning representerer ungdom i dag hovedsakelig prokulturer. Det er i all hovedsak en «snill» ungdomsgruppe som reflekterer og etterlever samfunnets verdier (Tylden, 2016).Våre funn antyder samme tendens og informantenes fortellinger viser et behov for tilhørighet, ønsker om å bli akseptert og høre til, uten at prestasjoner blir målt.

Anne tok med seg et bilde der hun var relativt ung, mens hun spilte fotballkamp i et annet land. Faren hennes var fotballtrener og var med på å starte opp jentefotball i dette landet. Hun forteller:

Jeg har vært i xxx et par ganger, så dette var første gangen. Det var i [...], så jeg var 11 år. De jeg spilte på lag med og spilte mot der, var vel 4 år eldre enn meg. Så når jeg kom ut på den banen, så var det bare menn på tribunen, det var stappfullt. $\mathrm{Og}$ alle reiste seg og jublet for jeg var så liten og lav, og jeg var så annerledes enn de andre. Så det var veldig spesielt (Anne).

Foreldrene har tatt henne med på reise fra Norge til et fremmed land og latt henne delta i en fotballkamp. Hun fortsatte å spille fotball opp gjennom oppveksten og ungdomstiden. Hun spilte fotball på et høyt nivå da hun ble skadet og måtte ta en pause. Fotballen har allikevel en svært sentral rolle i livet hennes liv. Hun fortsetter:

Det er jo sånn at jeg husker alt. Det betyr jo på en måte mye, for da husker jeg hvordan det var å være der, og alle inntrykkene jeg fikk. Samtidig så valgte jeg et bilde der jeg spiller fotball, for jeg spiller fotball. Men så har jeg vært skadet i to år, så jeg har ikke spilt fotball på veldig lenge. Så da betyr det litt ekstra mye (Anne).

Å prestere godt i idrett vitner om at utøveren har god helse, jobber målrettet og er utholdende. Det gir prestisje og sosial status i ungdomsmiljøer (Tylden, 2016). Dette kan således knyttes til den delen av individualiseringstesen som omhandler hva ungdommen er frigjort til. En slik tolkning vil kunne innebære at i Annes selvrefleksive prosjekt er helse, kropp og selvkontroll viktig. En annen og kanskje like rimelig tolkning er Annes deltakelse i fotball handler om et behov for tilhørighet og felleskap, og at det kanskje er viktigere for henne enn det er å trene og prestere. I intervjuet med Henrik kommer dette enda tydeligere fram. Han snakker eksplisitt om tilhørighet til 
gruppen av fotballsupportere. Også Kari, som er personlig kristen, uttrykker tydelig hvordan hun forsøker å knytte seg til et religiøst fellesskap.

Ungdommene er frigjort til et nyliberalt samfunn hvor de som enkeltindivider er tvunget til å måtte prestere på mange arenaer. Det er også ganske lite kontroversielt at de institusjonelle rammene er uklare og at manglende prestasjoner også blir individualisert (Brown, 2016). Vendingen mot fellesskapet i supporterklubber og i religiøse grupper kan ses som et forsøk på å holde prestasjonssamfunnet de er frigitt til på avstand. De virker som de ønsker å knytte seg til felleskap der prestasjoner betyr mindre enn tilhørighet. Samme tolkning kan legges til grunn i møte med bildene og fortellingene til Louise og Stian. I Louises tilfelle, gis vi en historie knyttet til et bilde av en strand i solnedgang. Hun forteller om landet hennes foreldre flyttet fra og om hvordan det er å reise dit på ferie. Hennes fortelling handler eksplisitt om en lengsel etter familiens røtter, men samtidig om en type flukt fra det hun synes er en stressende hverdag. Hun forteller "[...] at det er så mye, her, så er det veldig mye stress og du er nødt til å jobbe og alt skole og sånne ting [...]». Bildet drar henne inn i en annen, romantisert verden, som ifølge henne selv gir henne en ro og indre fred, noe hun synes å mangle $i$ hverdagen. Louise forteller at bilder får henne til å drømme seg inn i en romantisert verden. Dette fremstår som en flukt bort fra hverdagens stress, forventninger og prestasjonspress. Hun antyder i stor grad en maktesløshet og manglende tro på at hun kan gjøre en forskjell.

Et annet eksempel på en informant som på en paradoksal måte representerer et behov for å slippe å være i endring er Stian. Han tok med seg flere bilder til intervjuet. Ved første inntrykk kan man ane en frihets- og utreisetrang hos den unge mannen. Han viste nemlig bilder fra ulike steder i verden; Eiffeltårnet i Paris, Mount Everest og New York. Dette var steder han ville besøke i løpet av livet, forteller informanten oss først. Deretter presenteres en personlig fortelling om et minne han hadde fra barndommen hvor han var i Paris med sin far og stemor. Han var den gang for liten til å se utover kanten øverst i Eiffeltårnet og ville derfor gjenta denne reisen dit slik at han fikk gjort akkurat det. Han ville også kjøpe den blå fuglen som han ikke fikk kjøpe av en gateselger ved foten av Eiffeltårnet. Det var snakk om en ufullendt reise som han ønsket å gjenta. Ikke minst hadde han medbrakt bilder av ulike byer fordi han selv har hatt sin oppvekst i byen og opplever en trygghet ved byens mange mennesker, både når det gjelder lukt, lyder og liv. Han sa blant annet følgende:

«Jeg er jo vokst opp i by og jeg er veldig glad i byen. Jeg kunne aldri bodd noe annet sted enn i en by. [...] jeg vet hvordan det er å alltid ha hatt gaten som på en måte sted å leke på og sånne ting, da. [...] ja, jeg liker alt med det [bylivet] egentlig. Det samler folk...". (Stian)

Om bildet av Mount Everest fremhever han tidløsheten og det uforanderlige:

«Og så noe med fjell er den tidløsheten som de har da. At fjell har jo alltid vært. Selv om du ikke kjenner igjen et fjell, så vet du at fjell har alltid vært der. De kommer alltid til å være. Eller, de blir jo mindre og mindre med årene. Noen blir større, men 
de er stort sett de samme. De vokser ikke så mye. [...] De forandrer seg ikke. [...] Ja, jeg liker ikke forandringer egentlig». (Stian)

Vi merker oss at Stian "opplever en trygghet ved byens mange mennesker», at han «liker alt med det [bylivet] egentlig. Det samler folk...» og at han ikke liker «forandringer egentlig». Stian presiserer at han ikke liker forandringer og det er således fornuftsstridig å tolke dette annerledes enn at bildene og fortellingene viser et ønske om stabilitet, til tross for at reise kan oppfattes som noe ustabilt. Vårt materiale tyder her ikke på at det er frihet fra felleskap og fasthet rammer disse ungdommene ønsker. En bedre tolkning synes å være at de vil frigjøre fra de individuelle krav til prestasjoner og vellykkethet.

\section{Individualiseringstesens dobbelthet - frigjøring fra og frigjøring til}

Våre funn peker på at familien har stor betydning for ungdommer. Disse funnene har støtte i Wyn m.fl. sin forskning, som nettopp hevder at familiens betydning for ungdom snarere øker enn minker.

We note that making an argument about the increasing significance of families that draws on the individualization thesis of fragmenting institutional and traditional structures in late modernity may seem to be a contradiction (2012, s. 4).

De argumenterer for Beck's tese om individualisering ikke bare handler om at «individuals are 'freed' from institutional and traditional ties», men at individualiseringsprosessene også påtvinger den enkelte flere byråkratiske og institusjonelle ordninger (Wyn m. fl., 2012, s. 4). Vi mener at vi ved å splitte individualiseringstesen til BBG i en del som omhandler de sosiale institusjonene som ungdommen frigjøres fra og skiller det fra de institusjonelle rammene som ungdommen frigjøres til, langt på vei oppløser denne kontradiksjonen og tilfører diskusjonen et viktig analytisk nivå. Vår analyse antyder at ungdommene nok er frigjort til et nyliberalt individualistisk samfunn, men funnene tyder også på at de for å klare seg i dette samfunnet har et større behov for å knytte seg tettere til familie og andre fellesskap, ikke frigjøre seg fra dem. Vi mener å kunne se i våre data et økende behov for ungdom til å være forankret til et fellesskap for å kunne håndtere det samfunnet de er tvunget til å være frigjort til.

\section{Tilknytning og fellesskapsrefleksivitet som forutsetning for selvrefleksivitet} og frigjøring?

Den konvensjonelle stereotypien av en ungdom for et par tiår siden framstilte ungdom som selvopptatt, selvrealiseringssugne, narsissistiske og planla et liv i rampelyset (Lasch, 1982). I den moderate varianten (som vi har vektlagt her) var ungdommen tvunget til individualisering og selvrefleksivitet i det de var frigjort til å velge livspartnere, bosted, parti, utdanning, klær, seksualitet osv. Beck (1992) og Giddens (1991; 
1994). I Norge kunne Marianne Gullestad (1996) gjennom en studie av ulike klasser og generasjoner rapportere om at den yngste generasjon var mest opptatt av seg selv og sine egne drømmer. Det er ikke denne formen for frigjøring til et samfunn med rom for selvrealisering som preger informantene i vårt materiale. De er selvrefleksive og bevisst mulighetene og ansvaret som pålegges enkeltindividet. Men kanskje må vi tolke funnene slik at denne frigjøringskulturens krav til prestasjoner og individuell suksess allerede er internalisert i dagens ungdomsgenerasjon. Eksterne ytre krav (for eksempel statens krav om å prestere i skolen, «ansvar for egen læring») har blitt omgjort til individuelle interne krav, og - en type governmentalitet - er internalisert som individuelle ønsker eller krav til seg selv (Foucault, 1997). Kanskje er dette noe de har lært seg å akseptere, og at de derfor er mindre opptatt av kravene om å ta ansvar for hele seg og derfor bare i liten grad eksplisitt distanserer seg fra kravene til utseende og intellektuelle prestasjoner. Når Øia og Vestel oppsummer og diskuterer funnene fra Ung i Oslo (1996, 2006, 2012), og hevder at tidligere tiders oppfattelse av ungdomstiden som en opprørsk og opposisjonell fase må vike til fordel for en ungdomsgenerasjon som står i en «ny, mer "positiv» og dialogisk relasjon» til eldre generasjoner (Øia \& Vestel, 2014), kan det tyde på at disse samfunnskravene (ofte også foreldres krav) har blitt deres egne.

Hvis vi godtar disse funnene og at hverdagen til mange vestlige ungdommer er preget av konkurranse og rivalisering (Vetlesen, 2009), lever dagens ungdom i et prestasjonssamfunn med større press for å ha et bra utseende, riktige klær og mange og nære venner. Dette presset er ikke lenger noe ungdommen så lett kan ta seg fri fra - det er dette de er frigjort til - og presset blir ytterligere intensivert siden de alltid kan være pålogget sosiale medier som konstant minner om disse kravene. I tillegg har forventninger om gode skoleprestasjoner økt. Mangfoldet av fag har blitt ofret til fordel for drilling av bestemte ferdigheter. Disse endringene i skolen har blitt gjennomført samtidig som det er i ferd med å etablere seg en massiv kultur for kartlegging, måling og evaluering (Skarpenes \& Nilsen, 2014). Presset på den enkelte er derfor stort og det er naturlig at mange opplever det som massivt. I de verste tilfeller fører det til depresjoner og andre psykiske lidelser. Denne situasjonen kan godt beskrives som risikofylt (Beck, 1992), urolig og flytende (Bauman, 2000), og refleksiviteten knyttet til dette ser ut til å ha blitt "common sense», det er noe de tar gitt. De vet at de er tvunget til selvrefleksivitet.

Individualiseringstesen ble oppfattet slik at subjektet måtte løsrive seg fra tradisjonelle institusjoner som familie for å bli frigjort til selvrefleksive individ. En slik tolkning ligger også tett på den tesen slik den er utlagt av Beck og Giddens. Ved å dele tesen i en "frigjøring fra del» og en «frigjøring til del» har vi forsøkt å vise at det virker å være viktig for ungdomsgenerasjonen at de er forankret i familien gjennom nærhet og gjensidighet, og videre, at denne tilknytningen er en nødvendig betingelse for at den skal kunne være frigjort og individualisert. Tilknytningstesen antyder en generasjon som har stor innsikt $\mathrm{i}$ betydningen av familien og andre felleskap for at den skal fungere på andre arenaer. Generasjonen synes å være tvunget til felleskapsrefleksivitet like mye som selvrefleksivitet. 


\section{Ane Malene Saverot og Ove Skarpenes}

\section{Biografi}

Ane Malene Sæeverot er PhD.-stipendiat ved Institutt for pedagogikk ved Universitetet i Bergen. Forsker innenfor temaene (1) bildeteori; (2) ungdom og eksistensielle forhold og (3) pedagogisk teori og praksis.

Ove Skarpenes er professor i sosiologi ved Universitetet i Agder. Forsker særlig innenfor tre temaer: (1) kultursosiologi og klassesosiologi; (2) utdanningspolitikk og -reformer og skolefag og (3) vitenskapsteoretiske og kunnskapssosiologiske problemstillinger.

\section{Referanser}

Aakvaag, G.C. (2013). Hva skal dagens unge bruke stemmeretten til? Hentet 22.09.17 fra http://www.aftenposten.no/meninger/kronikker/Hva-skal-dagens-ungebruke-stemmeretten-til-7295510.html\#. Ui2SM-OTsVc

Atkinson, W. (2010). Class, individualization and late modernity: In search of the reflexive worker. Houndmills: Palgrave Macmillan.

Bakken, A. (2016). Ungdata 2016. Nasjonale resultater. NOVA Rapport 8/16. Hentet fra: http://www.hioa.no/ Om-HiOA/Senter-for-velferds-og-arbeidslivsforskning/NOVA/Publikasjonar/Rapporter/2016/ Ungdata-2016.-Nasjonale-resultater

Banks, M. (2007). Using Visual Data in Qualitative Research. London: Sage.

Bauman, Z. (2000). Savnet fellesskap. Oslo: Cappelen Akademisk Forlag.

Bauman, Z. (2001). Flytende modernitet. Oslo:Vidarforlaget.

Beck, U. (1992). Risk society: Towards a new modernity. London: Sage.

Beck, U. \& Beck-Gernsheim, E. (2002). Individualization. London: Sage.

Biesta, G. (2014). The beautiful risk of education. USA, Boulder: Paradigm Publishers.

Bingham, C. \& Biesta, G. (2010). Faques Rancière. Education, truth, emancipation. London, NewYork: Continuum.

Bourdieu, P. 1999. Moteld. Texter mot nyliberalismens utbredning. Stockholm: Brutus Östlings Bokförlag Symposium.

Brannen, J. \& Nilsen, A. (2005). Individualisation, Choice and Structure: A Discussion of Current Trends in Sociological Analysis. The Sociological Review, 53(3), 412-427.

Brown, W. (2016). Undoing the Demos. Neoliberalism's Stealth Revolution. New York: Zone books.

Foucault, M. (1997). Ethics. Subjectivity and truth. New York: New Press.

Giddens, A. (1991). Modernity and self-identity. Self and society in the late modern age. Cambridge: Polity Press.

Giddens, A. (1994). Intimitetens forandring: seksualitet, kcelighed og erotik $i$ det moderne samfund. København: Reitzel Forlag.

Giddens, A. (1997). Modernitetens konsekvenser. Oslo: Pax forlag.

Grue, L. (1987). Ungdom uten opprør? En rapport om attenåringers aktiviteter og holdninger. Oslo: STUI.

Gullestad, M. (1996). Hverdagsfilosofer. Oslo: Universitetsforlaget.

Hansen, M. N. \& Engelstad, F. (2010). Samfunnsklasser og eliter. I I. Frønes \& L. Kjølsrød (red.), Det norske samfunn (s. 191-213). Oslo: Gyldendal Akademisk.

Harvey, D. (2005). Den nye imperialismen. Oslo: Oktober.

Heggen, K. \& Øia, T. (2005). Ungdom i endring: mestring og marginalisering. Oslo: Abstrakt forlag.

Helseth, H. (2012). Generasjon sex. Oslo: Manifest.

Irwin, S. (2009). Family contexts, norms and young people's orientations: researching diversity. Fournal of Youth Studies, 12(4), 337-354.

Kjærnsli, M. \& Olsen, R. V. (2013). Fortsatt en vei å gå. Norske elevers kompetanse i matematikk, naturfag og lesing i PISA 2012. Hentet fra http:/www.udir.no/contentassets/478ff813bbdd4a6298f9a9ea646c48e3/ pisa-2012-norske-resultater.pdf

Krange, O. \& Øia, T. (2005). Den nye moderniteten: ungdom, individualisering, identitet og mening. Oslo: Cappelen. Lasch, C. (1982). Den narsissistiske kultur. Oslo: Pax.

Lareau, A. (2002). Invisible inequality: social class and childrearing in black families and white families. American sociological review, 67(5), 747-776.

Lillejord, S., Halvorsrud, K., Ruud, E., Morgan, K., Freyr, T., Fischer-Griffiths, P., Eikeland,O. J., Hauge, T. E., Homme, A. D., Manger, T., Kirkebøen, L. J. \& Sandsør, A. M. J.(2015). Frafall i videregående opplaring: En 


\section{Familien og felleskapets betydning $i$ skoleelevenes selvpresentasjoner}

systematisk kunnskapsoversikt. Oslo: Kunnskapssenter for utdanning. Hentet fra https://www.regjeringen. no/contentassets/1e632f4a6e434af2b67950dc45aa2ffe/frafall_rapport_ksu_e.pdf

Madsen, O.J. (2014). «Det er innover vi må gå» En kulturpsykologisk studie av selvhjelp. Oslo: Universitetsforlaget. Nilsen, A.C.E. (2016). Bekymringsbarn blir til. En institusjonell etnografi av tidlig innsats som styringsrasjonale $i$ barnehagen. P.hd.-avhandling i sosiologi, Institutt for sosiologi og sosialt arbeid, Universitetet i Agder.

Rancière, J. (2009a). The future of the image. London/ New York: Verso.

Rancière, J. (2009b). The emancipated spectator. London/ New York: Verso.

Rancière, J. (2011). The politics of aesthetics. London/ New York: Continuum.

Reegård, K. \& Rogstad, J. (red.). (2016). De frafalne: om frafall $i$ videregående opplering.Oslo: Gyldendal Norsk Forlag.

Rose, G. (2012). Visual methodologies. An introduction to Researching with Visual Materials. London: Sage.

Seljestad, L.O. (2003). "Frisatt eller forankra?». Sosiolog-nytt, 28 (2), s. 7-18.

Sennett, R. (1998). The Corrosion of Character. The personal Consequences of Work in the New Capitalism. New York/ London: W. W. Norton \& Company.

Sjøberg, S. (2014). PISA-syndromet - Hvordan norsk skolepolitikk blir styrt av OECD. Nytt Norsk Tidsskrift, $31(1), 30-43$.

Skarpenes, O. \& Nilsen, A.C.E. (2014).'Making up pupils’. Norsk Pedagogisk Tidsskrift, 98(06), 424-439.

Skarpenes, O. \& Sæverot, A.M. (2018). Symmetry and equality - bringing Rancière into the classroom. In Contemporary Issues in Early Childhood. Sage (in press).

Standing, G. (2014). Prekariatet: den nye farlige klassen. Oslo: Res publica.

Sæverot, A. M. (2015). Bilders eksistensielle betydning for ungdom. I P.O. Brunstad, S.M. Reindal \& H. Sæverot (red.). (2015). Eksistens og pedagogikk: en samtale om pedagogikkens oppgave. Oslo: Universitetsforlaget.

Sæverot, A.M. \& Ulvik, M. (til vurdering). Bruk av bilder $i$ undervisning.

Turtiainen, P., Karvonen, S. \& Rahkonen, O. (2007). All in the Family? The Structure and Meaning of Family Life among Young People. Fournal of Youth Studies, 10(4), 477-493.

Tylden, H. (2016). Statushierarkier blant ungdom i Norge (Master oppgave, Institutt for sosiologi og sosialt arbeid), Universitetet i Agder.

Vassenden, A. \& Andersson, M. (2010). When an image becomes sacred. Photo elicitation using images of holy books. Visual Studies, 25(2), 149-161.

Vetlesen, A. J. (2009). Fellesskap i individualismens tidsalder I H. E. Nafstad \& R.M. Blakar (red.). Fellesskap og individualisme (s. 19-54). Oslo: Gyldendal Akademisk.

Vogt, K. C. (2017). Vår utålmodighet med ungdom. Tidsskrift for samfunnsforskning, 58(1), 105-119.

Wyn, J., Lantz, S. \& Harris, A. (2012). Beyond the 'transitions' metaphor Family relations and young people in late modernity. Fournal of Sociology, 48(1), 3-22.

Øia, T. (1998). Generasjonskløfta som ble borte: ungdom, innvandrere og kultur. Hentet 22.09.17 fra http:// www.nb.no/nbsok/nb/b1d645c9cb8c333cd41848f84e486ff2.nbdigital?lang=no\#4

Øia, T. \& Fauske, H. (2010). Oppvekst $i$ Norge. Oslo: Abstrakt forlag.

Øia, T. \& Vestel, V. (2014). Generasjonskløfta som forvant. Tidsskrift for Ungdomsforskning, 14(1), 99-133. 